\title{
TRTaKadeMi
}

ISSN 2149-9446 | Cilt 06 | Sayı 11 | Ocak 2021 | Büyük Veri

\section{Uluslararası Haber Kanalı TRT World'ün Kovid-19 Küresel Pandemi Krizi Döneminde Sosyal Medya Kullanımı}

\author{
BAHADIR AVŞAR
}

\begin{abstract}
Öz
Kovid-19 salgın sürecinde insanlar haber kaynağı olarak sosyal medyayı daha yoğun bir şekilde kullanmaya başlamışlardır. Türkiye'nin İngilizce yayın yapan kanalı TRT World'ün pandemi döneminde yaptığı sosyal medya paylaşımları bu çalışmanın temel çıkış noktasını oluşturmaktadır. Bir kamu yayıncısı olarak TRT World İngilizce uluslararası haber üreten bir televizyon kanalıdır. Bu çalışmanın amacı TRT World'ün pandemi sürecinde Twitter'dan ürettiği içeriğin kriz haberciliği açısından değerlendirilmesidir. Bu bağlamda TRT World resmî Twitter hesabında, pandemi ile ilgili haber içerikleri analiz edilmiştir. Kriz dönemleri sorumlu kamu yayıncılığının önemini artıran bir unsurdur. Yeni Türkiye'nin Küresel Sesi TRT World'ün (Devran, 2015:281) Kovid-19 krizi döneminde sosyal medya içeriklerinin çözümlemesinin bilimsel alana katkı sağlayacağı düşünülmektedir. Bu analizler duygu ve içerik analizi yöntemleriyle yapılmıştır. Yapılan analizlerde TRT World'ün küresel ve sorumlu habercilik anlayışı ile haber ürettiği sonucuna ulaşılmıştır. Kovid-19 salgınından yoğun etkilenen bölgelere ilişkin gerçek hızlı ve nesnel verileri, kriz dönemi sorumlu habercilik anlayışı ile işlediği tespit edilmiştir. TRT World'ün insanları bilgilendirmeye yönelik olarak düzenli bir biçimde haberlerini sosyal medyadan sunduğu görülmüştür. Belirtilen veriler sonucunda TRT World pandemi sürecinde kriz haberciğini sosyal medya üzerinden başarılı bir şekilde uygulamıştır.
\end{abstract}

Anahtar Kelimeler: TRT World, Kovid-19 Salgını, Kriz, Sosyal Medya, Twitter, İçerik Analizi

\section{Araştırma Makalesi}

Geliş Tarihi: 17.11.2020

Kabul Tarihi: 18.01.2021

ORCID ID: 0000-0002-6805-537X DOI: 10.37679/trta.827453

E-mail: bahadir.avsar@trt.net.tr 


\title{
TRTaKadeMi
}

ISSN 2149-9446 | Volume 06 | Issue 11 | January 2021 | Big Data

\section{International News Channel TRT World's Social Media Usage During the COVID-19 Pandemic Crisis}

\author{
BAHADIR AVŞAR
}

\begin{abstract}
During the COVID-19 epidemic, people began to use social media more intensively as a news source. Social media shares made by Turkey's English-language channel TRT World during the pandemic crisis, constitute the main starting point of this article. As a public broadcaster, TRT world is a tv channel that produces international news in english. The main point of this article is to evaluate the content that TRT World shares on Twitter during the pandemic in terms of Crisis Reporting. In this context, News content related to the pandemic was analyzed on TRT World's official Twitter account. Times of crisis are a factor that increases the importance of responsible public broadcasting. Global voice of the new Turkey's TRT World's (Devran, 2015:281) analysis of the social media during the pandemic crisis is expected to contribute to the scientific analysis of social media content. These analyses were performed using emotion and content analysis methods. In the analyses conducted, it was concluded that TRT World produces news with an global and balanced journalistic mentality. It is understood that it processes real, rapid and objective data about the regions heavily affected by the COVID-19 epidemic, with the understanding of responsible reporting during the crisis. It has been observed that TRT World regularly presents its news on social media in order to inform people. As a result of the data stated, TRT World successfully implemented Crisis Reporting through social media during the pandemic process.
\end{abstract}

Keywords: TRT World, COVID-19 Pandemic, Crisis, Social Media, Twitter, Content Analysis

Research Paper

Recieved: 17.11 .2020

Accepted: 18.01.2021

ORCID ID: 0000-0002-6805-537X DOI: 10.37679/trta.827453

E-mail: bahadir.avsar@trt.net.tr 


\section{Giriş}

Insanın bilgiyi depolayarak diğer insanlara ve nesillere aktarması tarih boyunca farklı şekillerde gerçekleşmiştir. İnsanoğlu mağara duvarlarına resim çizerek ya da konuşarak bilgiyi her seferinde daha da güçlü bir şekilde soyutlamayı başarmıştır. Bu konudaki en önemli eşik ise yazının icadıdır. Yazı, insanın iletişim gücünü devrimsel bir nitelikte artırırken onun daha karmaşık siyasi, ekonomik ve teknolojik yapılar kurmasının da önünü açar. Yazıyı icat eden insan önceki dönemlere göre çok daha karmaşık toplumsal yapıları inşa edebilmiş, bu sayede bilgi dağarcığını çok daha fazla bir şekilde aktararak çok büyük şehirler, ülkeler kurmayı başarmıştır. Yazının icadından günümüze kadar gelen süreçte insanoğlunun kurduğu sosyal yapılar daha büyük ve daha karmaşık bir hâl alırken enformasyon da hızla soyutlanmakta; zaman ve mekânı her bir teknolojik ilerleme sonrası daha da sıkıştırmaktadır.

Bilgiye ulaşmayı toplumsal bir ayrıcalık olmaktan çıkaran matbaanın icadı, bir enformasyon kaynağı olarak gazeteleri yaygınlaştırmış; daha çok bilgiye, çok daha fazla insanın ulaşması enformasyonun katlanarak artmasını sağlamıştır. Telgraf teknolojisini radyo, televizyon, internet teknolojileri izlemiş ve her biri, o zamana kadar dünyanın görmediği düzeyde enformasyonun hızını katlayarak artırmıştır. Osmanlı döneminde bir ulak, İstanbul'dan aldığı bir padişah fermanını belki aylar sonra Mısır vilayetine götürebilirken bugünün dijital dünyasında herhangi bir vatandaş binlerce kilometre öteye canlı yayın yapabilmekte; bırakın aynı dili konuşanları, farklı dilleri konuşan insanlar çeviri teknolojileri kullanılarak bu canlı yayınlara katılabilmekte, hatta anlık yorumlayabilmektedir. Hatta üretilen bilgiyi alan, yorumlayan ve olabilecek en etkili bir şekilde tekrar biçimlendirip sunan yapay zekâ teknolojileri başlı başına enformasyon kaynağı hâline gelmiştir. San Francisco merkezli yapay zekâ araştirma laboratuvarı OpenAl tarafindan geliştirilen GPT-3 ${ }^{i}$ tarafindan üretilen metnin kalitesi o kadar yüksektir ki bir insan tarafindan yazılmadığını anlamak oldukça zordur (tr.wikipedia.org/wiki/GPT-3 Erişim Tarihi: 10.09.2020).

Her iki günde bir tüm uygarlığın ürettiği bilgi kadar dijital içeriğin üretildiği günümüzde (Schmid, Cohen, 2015:277) ikinci nesil internet teknolojileri (web 2.0) ile gelişen sosyal medya sayesinde her birey aynı zamanda potansiyel bir kitle iletişim aracına dönüşmüştür. Bunun sonucu ise büyük ve karışık bir iletişim ağı oluş-

\footnotetext{
'Generative Pre-trained Transformer 3 (Türkçe: Üretken Ön İşlemeli Dönüştürücü 3) şimdiye kadar üretilmiş en ilginç ve önemli yapay zeka sistemlerinden biri olarak 175 milyar veri işleme kapasitesine sahip. GPT-3 insanların yazdığı metinlere benzer içerik üreten için derin öğrenmeyi kullanan öz bağlanımlı dil modelidir. En büyük dil modeli Microsoft'un Şubat 2020 'de tanıttğı dil modeli GPT-3'ün \%10'undan daha az kapasiteye sahiptir.
} 
muştur. Castells'in vurguladığı gibi insanlar artık küresel ve yerel olarak örülmüş, birbiriyle bağıntılı küresel bir ağ toplumunda yaşamaktadır (Castells,2008:24). Bu yeni ağ toplumu Edvan. H. Potter'ın ifadesi ile hiyerarşik tek yönlü kitle iletişim modelini değiştirmiş, kullananlar engelsiz bir iletişim ağı içerisine girmiştir (Potter,2002:4-5). Yeni nesil internet teknolojileri ortaya çıkan ağ toplumunda birçok şey gibi kriz yönetimini de etkilemiş, değişmiş ve dönüştürmüştür. Bu dönemde krizler bilinmedik bir yerden çıkabilmekte ve emsalsiz bir hızla buhrana dönüşebilmektedir (Holtz 1999: 198).

Bir kamu yayıncısı olarak TRT World, İngilizce yayın yapmaktadır. Tüm dünyayı ilgilendiren konularda İngilizce haber üretmenin zorlukları Kovid-19 küresel pandemisi ile daha da hassaslaşmıştır. Bu süreçte tek yönlü asimetrik bir iletişim ortamı sunan konvansiyonel kitle iletişim araçlarının tersine iki yönlü ve simetrik bir iletişim ortamı sunan sosyal medyada sorumlu bir kamu yayıncılığı anlayışı ile içerik üretilmesi ise çalışmamızın ana problemi olarak nitelendirilebilir. Habere ulaşmada geleneksel kitle iletişim araçlarının yerini almaya başlayan sosyal medya Kovid-19 krizi ortamında iletişimsel yapısı özellikleri bakımından bazı dezavantajları da bünyesinde barındırır. Özellikle Kovid-19 salgını döneminde ortaya çıkan; salgın hakkında, sahte haberlerin yoğun olarak paylaşılması sonucu bilgi kirliliğinin yaşanması ve insanların doğru bilgiyi bulmakta zorlanmaları durumu olarak infodemi Kovid-19 ile mücadeleyi olumsuz etkilemektedir. Sanal ortamdaki manipüle edilen bilginin üzerine inşa edilmiş sahte gerçeklikler insanları korku ve paniğe sürüklemektedir ve bu tarz haberler gerçek haberlerden çok daha hızlı bir şekilde sosyal medyada yayılmaktadır. Sosyal medya ortamında kontrolsüz ve denetimsiz bir şekilde kötü niyetli kişiler tarafindan insanlarda korku ve panik havası oluşturmak, güvensiz bir ortam inşa etmek amacıyla asılsız ve gerçek dışı bilgiler içeren paylaşımlar yapılmaktadır. Kovid-19 krizi döneminde paniği artırma ve kaosa sürükleme potansiyeli yüksek olan sosyal medya teknolojilerinin iletişim ortamı TRT World gibi kamu yayıncılığı sorumluluğunda uluslararası yayın yapan kuruluşların önemini kritik düzeyde artırır. Bu doğrultuda çalışmamızın konusu, Kovid-19 krizi dönemi uluslararası kamu yayıncılığı yapan TRT World kanalının sosyal medya paylaşımlarıdır. Bu çalışmanın amacı TRT World'ün pandemi sürecinde Twitter'dan ürettiği içeriğin kriz haberciliği açısından değerlendirilmesidir. Türkiye'de yıllardır yapılmaya çalışılan ancak başarılı olunamayan; uluslararası alanda İngilizce haber yayıncılığı konusundaki büyük eksikliği TRT World gidermiştir. Bu anlamda Türkiye'nin küresel sesi olan TRT World (Devran, 2015:281) Türkiye'nin uluslararası yayın paradigmasını yeniden şekillendirmiştir. Yalnızca bu özelliği dahi TRT World'ün sosyal medya yayınlarının analizinin önemini artırmak- 
tadır. Kriz döneminde farklı kitle iletişim mecralarında, paniği artırma ve kaosa sürükleme potansiyeli yüksek içeriklerin yoğun olarak üretilmektedir. Bu doğrultuda Kovid-19 krizi döneminde TRT World'ün sosyal medya içeriklerinde tarafsız, sorumlu ve duygulardan arınmış niteliklere sahip bir kamu yayıncılığı yapıp yapmadığının anlaşılmasının alana katkı sağlayacağı düşünülmektedir.

Çalışmamızda; TRT World'ün Kovid-19 krizi döneminde ürettiği sosyal medyada paylaşımları, duygu analizi ve içerik analizi yöntemleri doğrultusunda analiz edilecek ve ortaya çıkan veriler doğrultusunda kriz dönemi sosyal medya habercilik anlayışı açısından TRT World'ün paylaşımları değerlendirilerek makale sonuçlandırılacaktir.

\section{Pandemi Dönemi Yayıncılık}

Fransızca kökenli olan kriz kavramı, Türk Dil Kurumu tarafindan bir ülkede veya ülkeler arasında, toplumun veya bir kuruluşun yaşamında görülen güç dönem, bunalım, buhran veya çöküntü olarak tanımlanır (sozluk.gov.tr). Toplumsal düzeni sarsma potansiyeli yüksek olaylar dizisi olarak kriz, ani gelişen, gündelik yaşamı etkileyen, değiştiren, kesintiye uğratabilen; terör, büyük kazalar, ekonomik buhran, doğal afet, savaş durumu, salgın hastalıklar gibi durumları kapsar. Normal zamanlarda insanların enformasyon ihtiyacını karşılayan kitle iletişim araçlarının önemini bu tarz kriz ortamları daha da artırmaktadır. Deprem, sel, yangın gibi felaketler ya da pandemi gibi kriz hâllerinin ortaya çıkardığı olağanüstü durumların insanlarda güvensizlik ve endişe oluşturduğu gibi kaotik ortamın enformasyon yoksunluğuna sebep olma durumu panik ve paranoya hâlini de beraberinde getirebilmektedir. Kriz ortamları, kulaktan dolma abartılı bilgiler, krizin oluşturduğu kaotik ortamın daha da büyümesine neden olur. Halk bu tarz durumlarda duyduğu her şeyi gerçek olarak algılamaya meyillidir. Toplumun çok büyük bir kesiminin, krizin ilk safhalarında eriştiği haber ve bilgileri eleştirel bir süzgeçten geçirip değerlendirmesini ya da öğrendiklerinin geçerliğini sınamasını beklemek gerçekçi değildir. Böylesi durumlarda gerçek bilgiye ulaşmak hayati bir önem kazanmaktadır. Tüm bu nedenlerden ötürü kriz durumlarında haberciliğin toplumsal önemi katlanarak artmaktadır (Çaplı, Taş, 2009:238).

Kovid-19 salgını küresel çapta bir salgın krizidir. Çin'in Hubei eyaletinin Vuhan şehrinde 31 Aralık 2019'da bilinmeyen pnömoni vakaları ile başlar. İlerleyen dönemlerde ortaya çıkan vakalarda Vuhan'ın güneyindeki Vuhan Güney Çin Deniz Ürünleri Şehir Pazarı (farklı hayvan türleri satan bir toptan balık ve canlı hayvan pazarı) çalışanlarında kümelenme olduğu belirlenir. Çin dışında ilk vaka 13 Ocak 2020'de görülmüş ve Mart 2020 tarihi itibariyle dünya genelinde yüzden fazla ül- 
kede Kovid-19 vakasına rastlanmıştır (tahud.org.tr/file/ac3d7f7f-752f-4f4f-97d43ea943204c8d/ Kovid-19_Rehberi-6-12.04.2020.pdf erişim 14 Ekim 2020). Mart 2020'de Dünya Sağlık Örgütü (DSÖ) tarafindan tüm dünyada pandemi ilan edilmiştir. Dört ay gibi kısa bir sürede 3 milyondan fazla kişiyi hasta eden ve iki yüz binden fazla insanın ölümüne neden olan bu hastalık, dünyada çok sıkı önlemler almayı zorunlu kılmıştır. Tüm dünya pandemi dönemine hazırlıksız yakalanmıştrr. Kovid-19 pandemisi sonrası ortaya çıkan sokağa çıkma yasakları sonrası ülkeler ekonomiden sosyal yaşantıya, eğitimden çalışma hayatına kadar her alanda olumsuz etkilenmiştir (Yanardağ, Selçuk, 2020:1). Özellikle pandemi gibi kriz ortamlarında, geleceğe yönelik belirsizlik duygusunu ortadan kaldırmak adına, sade ve doğru bilgiler içeren haberlerin mümkün olduğu kadar hızlı bir şekilde sunulması gerekir. Bunun yanında yayıncı, krize ilişkin profesyonel bir farkındalık oluşturma adına kriz ile ilgili uzmanların ve yetkililerin kriz hakkındaki açıklama ve yorumlarını da izleyici/dinleyiciye sunmakla sorumludur (Çaplı, Taş,2009: 240). Ayrıca yayıncı krizlerden fiziksel, ekonomik ya da duygusal olarak etkilenen kişilerin ihtiyaçlarını ve beklentilerini haberleştirme konusunda da sorumluluk sahibi olmalıdır (Karlı, 2020:172).

Görsel unsurları ve merak duygusunu kışkırtmayı ön plana alan, vurguyu artırma adına görüntü, ses ve müzik efektlerinin yoğun ve abartılı biçimde kullanıldığı, sürekli tekrar eden spotlar ve sloganlaştırılmış açıklamaların olduğu, somut gerçekler yerine birtakım yorumlar ve duygusal imgelerle oluşturulan haber kurguları daha çok izlenmek için kriz dönemlerinde yayıncılar tarafindan sıklıkla uygulanmaktadır. Bu tür haberler ise kriz dönemlerinde halkın kaygı düzeyini artıracağı gibi kaos durumunu da tetikleyebilir. Asparagas haber üreten kitle iletişim araçlarının ürettikleri haberler kriz dönemlerinde, krizi doğru bir şekilde anlamlandırmayı engelleyerek paniği tetikleyebilmektedir. Dolayısıyla kriz dönemlerinde sade ve bilgilendirici haber yapan, uzman yorumlarıyla insanları aydınlatmaya çalışan kamu yayıncılarının önemi kritik düzeyde artmaktadır.

\section{Araştırma Yöntemi}

Araştırmada nicel araştırma yöntemlerinden olan içerik analizi yönteminin yanında, TRT World'ün Twitter'da ürettiği içeriğin nesnelliğinin anlaşılması amacıyla duygu analizi yöntemi de kullanılmıştır. İçerik analizi işaretlerin sınıflanması ve bu işaretlerin hangi yargıları içerdiğini ortaya koymak için açıkça formüle edilmiş kurallar ışığında, araştırmacının ortaya koyduğu yargıların bilimsel değerlendirilmesini sağlayan nicel bir araştırma yöntemidir (Koçak, Arun,2006:22). İçerik analizi medya mesajlarındaki metinlerin görünen, kolayca belirlenen içeriğinin 
yerine kapalı alanlarını ortaya çıkaran bir yöntemdir (Bilgin,2014:1). Metindeki söylemin sayısallaştırılmasını ifade eden içerik analizi yoluyla görüş ve bilgileri objektif ve sistematik hâle getirir (Altunışık vd. 2010:322). Duygu analizi dijital içeriklerin olumlu, olumsuz ya da tarafsız içeriğe sahip olup olmadığının sorgulanmasıdır (Onan,2017:4). Duygu analizi internet ortamının olgular hakkındaki düşüncelerini ifade ettikleri elektronik platformlardaki büyük hacimli verilerin yazılım sistemleri ile hızlı olarak raporlanması ve anlam çıkartılması işlemidir (Tüysüz,2017:3). Duygu analizi sonucuna göre birey, grup, kurum veya yapının ilgili konu hakkındaki duygusal tutumunun öğrenilmesi amaçlanmaktadır. Yani duygu analizi yoluyla metinlerin onu oluşturan kişilerin konu hakkındaki duygusal tutumlarının anlaşılması hedeflenir (Safali ve diğ,2018:2). Araştırmada temel olarak sorguladığımız konu; TRT World'ün Kovid-19 krizi döneminde sosyal medyada, sorumlu bir yayıncılık anlayışıyla, anlaşılır ve basit bir dille haberlerini üretip üretmediğinin tespit edilmesidir. Bunun yanında uluslararası bir yayın kuruluşu olarak TRT World, Kovid-19 paylaşımlarının sosyal medyada potansiyel görüntülenmeleri ve paylaşımlarında kaç farklı bölgeden/ülkeden bahsettiği sorularının cevapları da aranacaktir.

Çalışmamız kapsamında Kovid-19 krizinin en yoğun yaşandığı, sokağa çıkma yasaklarının dünya genelinde yaygın bir şekilde uygulandığı Nisan 2020'de TRT WorId resmî Twitter hesabında (01-30 Nisan tarihleri arasında) üretilen tweet içeriği incelenmiştir. Öncelikle 1-30 Nisan 2020 boyunca yapılan tüm paylaşımlar tek tek indirilmiştir. Toplanan tweetler excel programında tarihi, içeriği, Twitter linki; retweet, beğeni, mention ve duygu durumu ve Kovid-19 ile alakalı olup olmama hâline göre ayrı ayrı tablolaştırılmıştır. Bu içeriklerde en sık kullanılan kelime öbekleri, terimler kelime bulutları şeklinde grafikleştirilmiştir. Verilerin grafiklere dönüştürülmesinde brandwatch.com ve adbaanalytics.com internet sitelerinden; Twitter içerik ve duygu analizi yapılırken ise twitonomy.com, seoscout.com ve keyhole.co internet sitelerinin sunduğu sistemlerden yararlanılmıştır.

\section{Bulgular}

TRT World'ün birden çok Twitter hesabından içerik ürettiği tespit edilmiştir. Anlık haber güncellemeleri için TRT World Now (@TRTWorldNow), sosyal sorumluluk faaliyetleri için TRT World Citizen (@TRTWorldCitizen), araştırma faaliyetleri için TRT World Research Centre (@TRTWorldRC), farklı topluluklara ulaşmak ve onlarla bağlant kurmak için TRT World Connect (@TRTWorldConnect), ve akademik faaliyetleri için TRT World Academy (@trtworldacademy) Twitter hesabıyla içerik ürettiği tespit edilmiştir. Bu kapsamda ilk olarak TRT World resmî Twitter hesabı 
belirlenmiştir. Resmî internet sitesinde (trtworld.com) ana sayfasında yönlendirilen Twitter hesabı TRT World (@trtworld), TRT World ana Twitter hesabı olarak tespit edilmiş ve bu hesaptan üretilen içerik baz alınarak analizler gerçekleştirilmiştir.

TRT World (@trtworld) resmî Twitter hesabı Mart 2015'te açılmış olup hesaptan 137 bin 749 tweet atıldığı anlaşılmaktadır. 348 bin 104 takipçisi ve 17 takip ettiği Twitter hesabı bulunmaktadır (twitonomy.com/profile.php?sn=trtworld erişim 11 Kasım 2020). Takip ettiği hesaplar yukarıda bahsi geçen diğer Twitter hesapları ve TRT Worldde yapılan programların resmî Twitter hesaplarıdır. Resim 1'de görüldüğü üzere Twitter profil fotoğrafinda TRT World logosu kullanılmıştır. Diğer dijital görselleri ile uyumlu olduğu gözlenen Twitter kapak fotoğrafinın TRT World'ün genel görsel konsepti ile bütünleşik olduğu anlaşılmaktadır. Twitter'ın belirlediği ölçülerde kapak ve profil boyutlarına özel olarak tasarlanmış görseller, uluslararası ölçekte haber üreten farklı televizyon kanallarının görsel konsept hassasiyetine benzer bir profesyonel hassasiyette tasarlandığı anlaşılmaktadır.

Resim 1: TRT World Resmî Twitter Hesabı

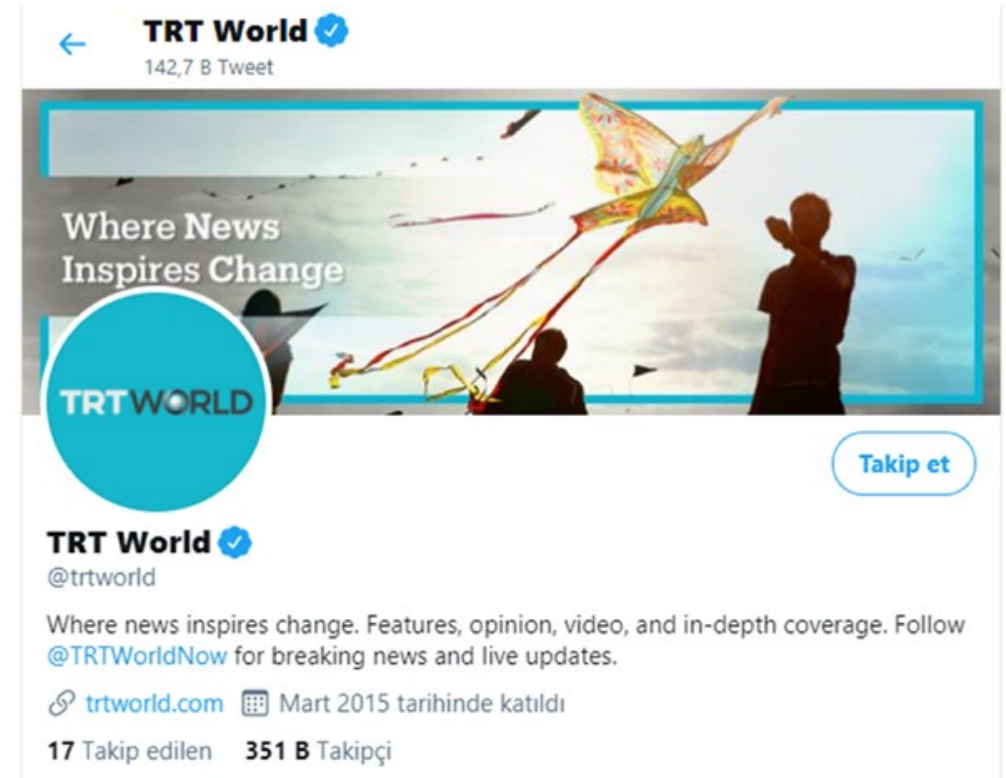

Twitter hesabının orijinal olduğunu gösteren mavi onay rozeti bulunan TRT World Twitter hesabında resmî internet sitesinin linki yer almaktadır. Kişisel bilgiler alanında ise "Where news inspires change. Features, opinion, video, and in-depth coverage. Follow @TRTWorldNow for breaking news and live updates." şeklinde 
bir metin bulunmaktadır. Hesap da günlük içerik üretilmekte aktif olarak kullanılmaktadır. 29 Eylül 2020 tarihinden 11 Kasım 2020 tarihine kadarki aralıkta hesabı incelediğimizde bu vakit aralığında 3200 tweet üretilmiş bu tweetler toplam 88 bin 486 kez retweet, 271 bin 596 kez beğeni almıştır. Yine bu tarih aralığında en yoğun kullandığı hashtag \%42,2 oranıyla "COVID-19" hashtagidir (twitonomy. com/profile.php?sn=trtworld).

TRT World resmî Twitter hesabından (@trtworld) Kovid-19 içeren paylaşımlara geçmeden önce 1 Nisan - 30 Nisan 2020 tarihleri arasında Twitter için üretilen içeriğe ilişkin bulguları değerlendireceğiz. 2020 Nisan ayı boyunca TRT World resmî Twitter hesabından, Kovid-19 paylaşımları dahil, toplam 2 bin 194 adet paylaşım yapıldığı belirlenmiştir. Bu tarihlerde potansiyel görüntülenme değerleri gün gün grafik 1'de detaylı bir şekilde yer almaktadır.

Grafik 1: TRT World Nisan 2020 Günlük Paylaşımlarının Potansiyel Görüntülenme Oranları

\section{Key Insights}
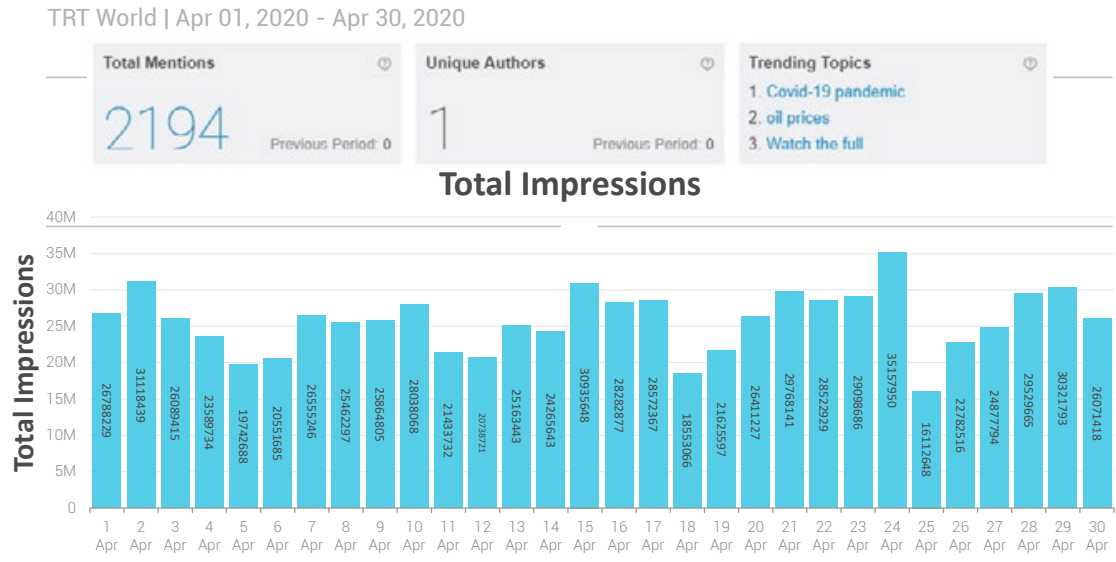

Grafikte her bir günü temsil eden mavi çizgilerin içerisinde, günlük potansiyel görüntülenme sayısı, üstünde ise o gün atılan tweet sayısı görülmektedir. Potansiyel görüntülenmeyi detaylı bir şekilde incelediğimizde 24 Nisan, 35 milyon potansiyel görüntüleme sayısı ile hesabın nisan ayında aldığı en yoğun etkileşimi bize gösterir. En az görüntülemeyi ise 16 milyon görüntüleme ile $25 \mathrm{Nisan'da} \mathrm{aldığı}$ tespit edilmiştir. Burada en dikkat çekici unsur en yoğun etkileşimin alındığı gün ile en az etkileşimin alındığı günün art arda gelmesi ve bu art arda gelen günde atılan tweet sayısının yarıya yakın azalmasıdır. Nisan ayı boyunca TRT World paylaşımları içerisinde en yoğun konuşulan konu Kovid-19 pandemisi olup diğer TT (Trend Topic) konuları grafik 1'de sağ üst köşede gösterildiği gibidir. 
TRT World'ün nisan ayı boyunca yaptığı tüm paylaşımların paylaşımları duygu analiz sonuçları ise Grafik 2'de görülmektedir.

\section{Grafik 2 : Nisan Ayı Boyunca Yapılan Paylaşımların Gün Gün Duygu Analizi}

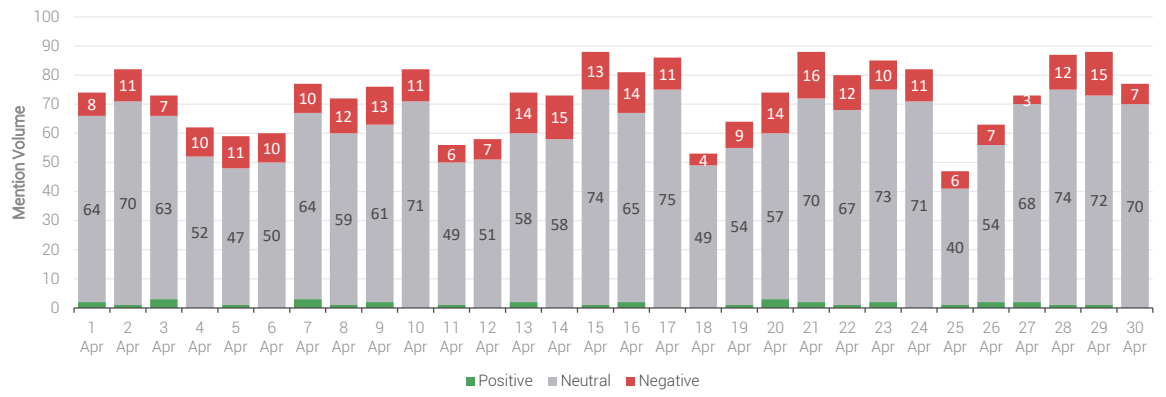

Tweetlerin \%2'si pozitif (35), \%14'ü negatif (309) ve \%84'ü tarafsız (1.850) içeriklidir. 21 Nisan en yoğun negatif paylaşımın yapıldığı tarih (88 tweetin 16 'sı negatif), 20 Nisan ise en yoğun pozitif paylaşımın yapıldığı (74 tweetin 4'ü pozitif) gün olarak dikkat çekerken 17 Nisan günü yapılan 75 paylaşımın duygu analizi sonucu tarafsız çıktığı gözlemlenmiştir.

TRT World nisan ayı Twitter paylaşımlarına ilişkin araştırmamız kapsamında ürettiğimiz diğer veriler ise kısaca şu şekildedir:

- Nisan ayı boyunca üretilen Twitter içeriklerinde en çok bahsedilen hesapların (mention) başında TRT World'ün diğer hesapları yer alırken, ABD-Türkiye İlişkileri Dış Politika Uzmanı, gazeteci @alicinar, İngiliz gazeteci @martinrjay ve haberci @hyderabbasi bahsedilen diğer Twitter hesapları olmuştur.

- En yoğun bayrak emojisi kullanılan ülke 25 tweetle Türkiye olup bu tweetler 7 milyon 911 bin 773 potansiyel görüntüleme almıştr. Ardından 22 tweette italya, 20 tweette İngiltere, 19 tweette ABD, 16 tweette Fransa, 11 tweette Almanya bayrağı emojisi kullanılmıştr.

- Paylaşımlarında en çok kullanılan kelimeler sırayla COVID-19, pandemic, spread, cases, lockdowndır. En çok ismi geçen ülke 223 kez Türkiye, 81 kez Çin, 73 kez Italya, 68 kez İspanya, 56 kez Almanya'dır. 


\subsection{Kovid-19 Paylaşım Bulguları}

TRT World resmî Twitter hesabı (@trtworld) 1 Nisan-30 Nisan 2020 tarihleri arasında ürettiği 2 bin 194 adet içeriğin bin 390 adedi Kovid-19 hakkındadır. Bu tarihlerde potansiyel görüntülenme oranları gün gün grafik 4'te yer almaktadır.

Grafik 4: Kovid-19 Paylaşımları Günlük Potansiyel Görüntülenme Grafiği

\section{Key Insights}

TRT World | Apr 01, 2020 - Apr 30, 2020
Total Mentions
Unique Authors
2194
Previous Penod 0

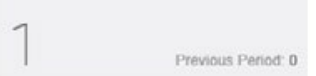
Trending Topics
Covid-19 pandemle
2. oll prices
Total Impressions

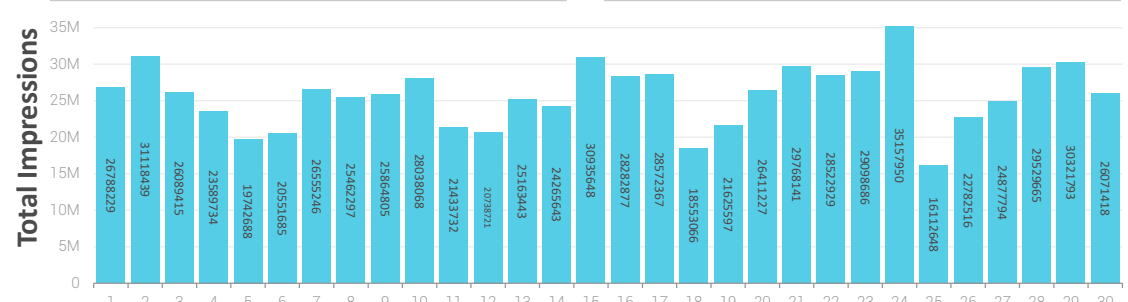

TRT World Kovid-19 paylaşımlarının potansiyel görüntülenme sayısı 488 milyon 596 milyon 597 olarak hesaplanmıştır. Paylaşımlarda 25 Nisan, 9 milyon 441 bin 538 ile en az potansiyel görüntülenme alınırken en çok potansiyel görüntüleme 10 Nisan'da gerçekleşmiş; TRT World Kovid-19 paylaşımları 10 Nisan'da 21 milyon 517 potansiyel görüntülenme sayısına ulaşmıştır. Gün gün paylaşım sayılarını ise detaylı bir şekilde Grafik 5'te işlenmiştir.

Grafik 5: Kovid-19 Günlük Paylaşım Hacmi

Volume $\quad$ • 1.390 adet paylașımın günlük olarak hacim dağılımı aşağıldaki grafikte yer almaktadır.

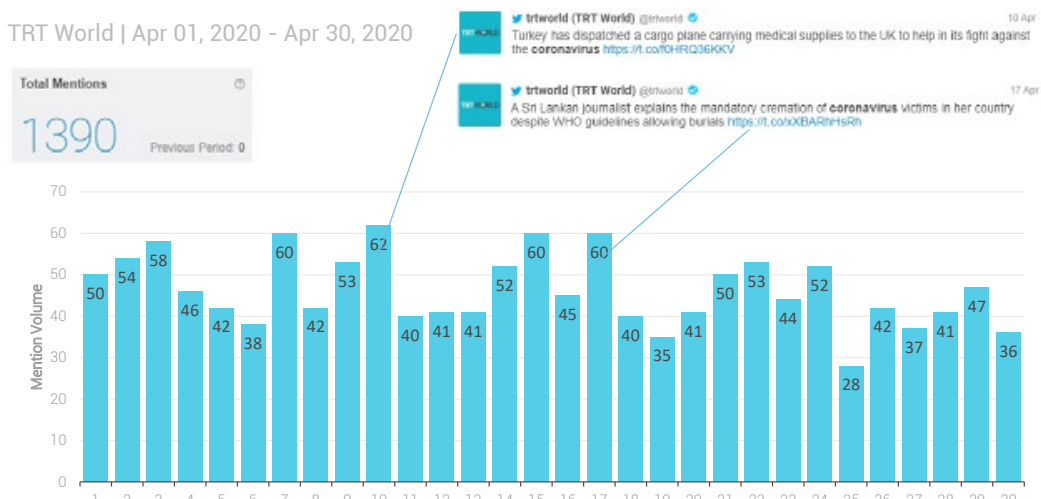


En yoğun Kovid-19 paylaşımı 10 Nisan'da 62 içerik üretimiyle gerçekleştirilirken Kovid-19 ile ilgili 28 paylaşımın yapıldığı 25 Nisan ise en az paylaşımın yapıldığı güne gelmektedir.

Bu veriler içerisinden ilk bakışta dikkat çeken; en çok paylaşımın yapıldığı gün en çok potansiyel görüntülemeye, en az paylaşımın yapıldığı gün, en az potansiyel görüntülenmeye ulaşıldığıdır. Nisan ayı boyunca yapılan genel paylaşım sayısı ve potansiyel görüntüleme oranları farklı günlere gelse de aynı mantıkta ilerlediği yani potansiyel görüntüleme sayısını artırmak için daha fazla içerik üretmek gerektiği anlaşılmaktadır.

Kovid-19 paylaşımları içerisinde etkileşimi en yüksek olan tweet Resim 2'de görülmektedir.

Resim 2: En Yüksek Etkileşim Alan Pandemi Paylaşımı

\section{TRT World 8}

@ trtworld

\section{Why are hashtags like \#CoronaJihad,}

\section{\#Nizamuddinldiots and \#Covid786 trending in India?}

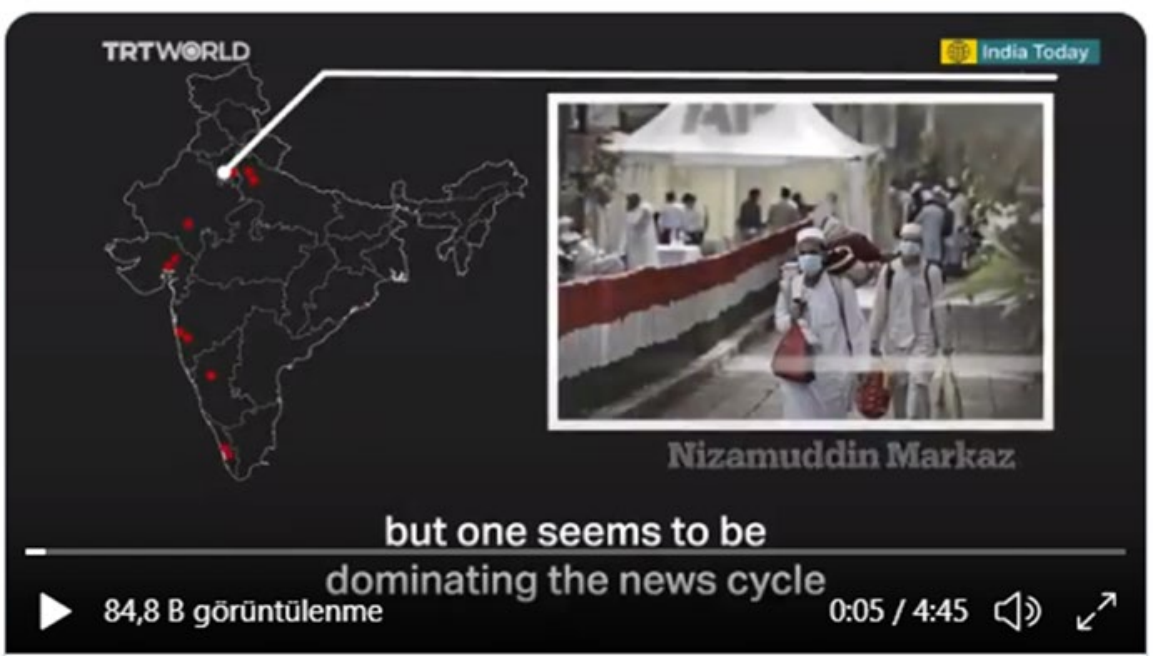

India: When Hindu nationalism meets Covid-19

ÖS 5:00 - 11 Nis 2020 . Twitter Media Studio

\section{1,4 B Retweet 215 Alıntı Tweet 2,2 B Beğeni}


11 Nisan 2020 05:00'te Twitter Media Studio ile oluşturulan "Why are hashtags like \#CoronaJihad, \#Nizamuddinldiots and \#Covid786 trending in India?" metni ile oluşturulmuş olan video içerikli paylaşım en yüksek etkileşim alan paylaşımdır. 96,6 etki değeri olan bu paylaşımın 2 milyon 515 bin 844 potansiyel görüntülenmesi bulunmaktadır. 346 yorum alan bu tweet 1400'ün üzerinde retweet 212 alınt ve 2,2 bin beğeni almıştır.

Kovid-19 paylaşımları içerisinde etkileşimi en düşük olan tweet ise Resim 3'te görülmektedir.

Resim 3: En Düşük Etkileşim Alan Pandemi Paylaşımı

The Newsmakers @ @ The_Newsmakers·2 Nis 2020

In March, more than 8,000 people died in Spain due to \#COVID19, the second highest death toll in the world.

So, why is the virus spreading so fast there? @HyderAbbasi reports.

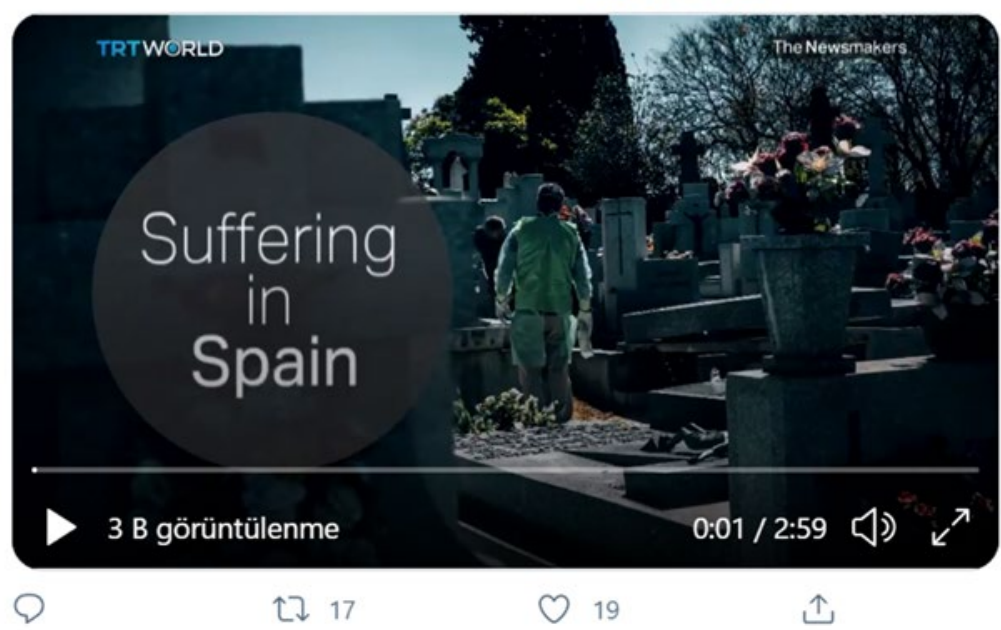

2 Nisan 2020 9:00'da Twitter Media Studio ile oluşturulan "In March, more than 8,000 people died in Spain due to \#COVID19, the second highest death toll in the world. So, why is the virus spreading so fast there? @HyderAbbasi reports."metni ile oluşturulmuş olan video içerikli paylaşımdır. 60,8 etki değeri olan bu paylaşımın 313 bin 777 potansiyel görüntülenmesi bulunmaktadır. 16 retweet, 1 alınt ve 19 bin beğeni almıştır.

TRT World Kovid-19 paylaşımlarının duygu analizi Grafik 6'da detaylı bir şekilde yer almaktadır. 
Grafik 6: Kovid-19 Paylaşımları Duygu Analizi

\section{Sentiment}

TRT World | Apr 01, 2020 - Apr 30, 2020

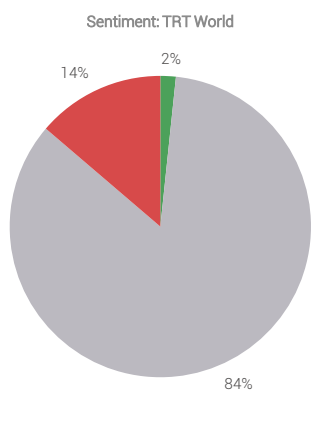

- Positive $₫$ Neutral @ Negative
@TRTworld hesabının Covid-19 hakkında yaptığı paylaşımların \%2'si pozitif (23), \%14'ü negatif (191) ve \%84'ü nötr (1.176) içerikli paylaşımlardan oluşmaktadır.

\begin{tabular}{cc} 
Sentiment $\Lambda$ & TRT World \\
\hline Negative & 191 \\
\hline Neutral & 1176 \\
\hline Positive & 23 \\
\hline
\end{tabular}

Grafikten de anlaşılacağı üzere TRT World, Kovid-19 için üretilen içeriklerin \%2'si pozitif (23), \%14'ü negatif (191) ve \%84'ü tarafsız (bin 176) içerikli paylaşımlardan oluşmaktadır.

Üretilen tweetlerin duygu analizinin günlere göre dağılımı grafikte 7'de görülmektedir.

Grafik 7: Kovid-19 Paylaşımları Duygu Analizi Günlere Göre Dağılımı

\section{Sentiment}

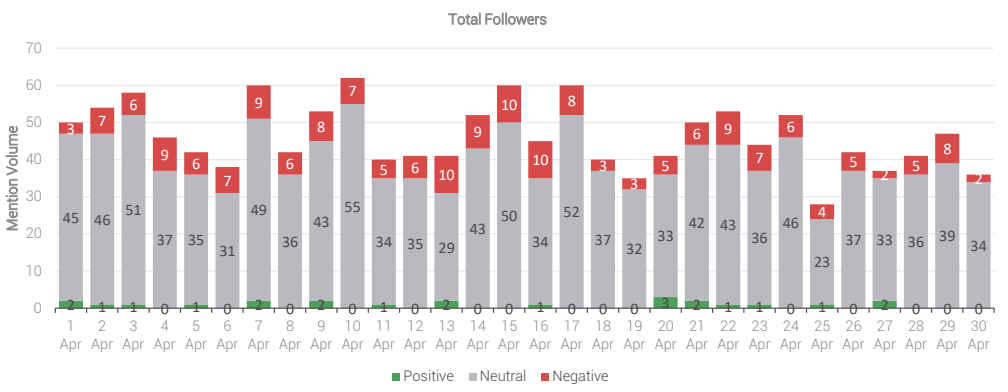

Çalışmada; TRT World resmî Twitter hesabından Kovid-19 hakkında üretilen 1390 içeriğin 23'ü pozitif, 191'i negatif 1176'sı ise tarafsız olarak tespit edilmiştir. Bir günde en yoğun pozitif içerik 3 pozitif tweet paylaşımı ile 20 Nisan'da, en yoğun 
negatif içerik 10 tweet paylaşımı ile 13-15-16 Nisan tarihlerinde, en yoğun tarafsız içerikli paylaşımın ise 52 tweet ile 17 Nisan'da gerçekleştirildiği görülmektedir.

Duygu dağılımına göre en çok kullandıkları kelime grupları grafik 8'de yer almaktadır. Grafik 8: Kovid-19 Paylaşımlarında En Çok Geçen Kelimeler ve Duygu Karşılıkları

\section{Topic Cluster}
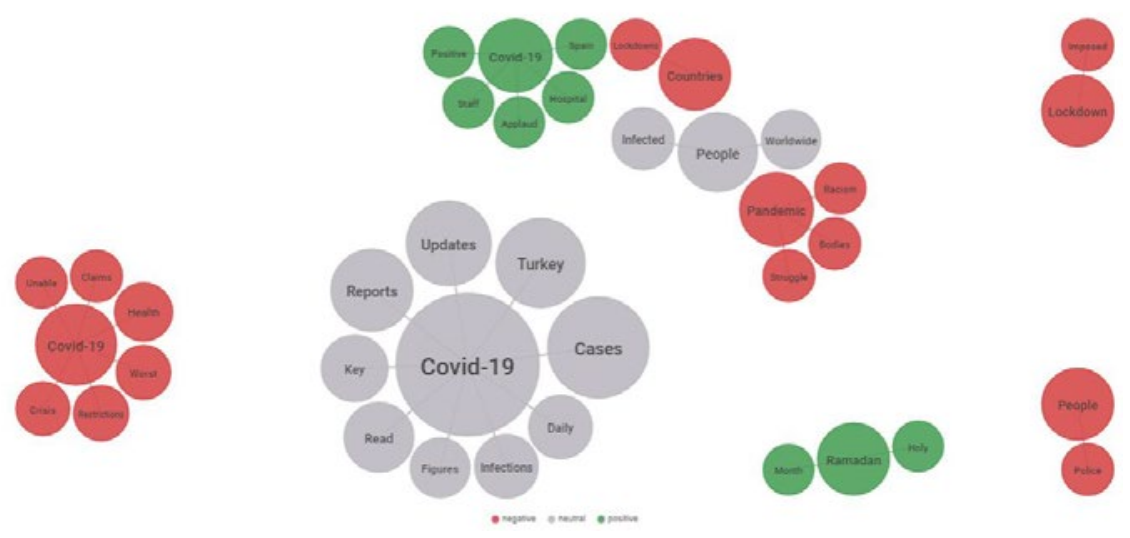

Kovid-19’a ilişkin duygu durumu tarafsız olan içeriklerde yoğun olarak Turkey, updates, cases, daily, reports gibi kelimeler kullanılırken olumlu içerikteki Kovid-19 paylaşımlarında hospital, positive, staff, spain ifadelerinin yoğun kullanıldığı tespit edilmiştir. Kovid-19 negatif paylaşımlarında yoğunlukla unable, claims, health, worst, crisis kelimelerinin tercih edildiği anlaşılmıştır.

Twitter paylaşımlarında en çok geçen kelimeler ve bu kelimelerin hangi duygu durumunu karşılayan tweet içeriğinde paylaşıldığı tablo 1'de yer almaktadır. 
Tablo 1: TRT World Kovid-19 Paylaşımlarında En Çok Geçen Kelime Tekrarları ve Duygu Karşılıkları

Topic Cluster

TRT World | Apr 01, 2020 - Apr 30, 2020

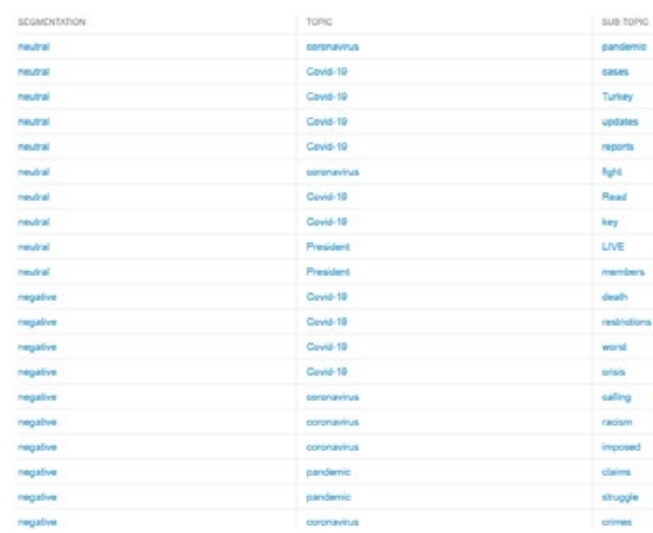

Tablo 1'de tüm detaylarını görebileceğimiz üzere tarafsız ve içerisinde Kovid-19 ifadesi geçen tweetlerde 116 kez cases ifadesi geçerken 82 kez "Turkey", 71 kez "updates", 64 kez "reports" ve 36 defa "read" ifadeleri geçmiştir. Tabloyu yorumladığımızda Kovid-19 küresel krizinde, insanları bilgilendirmeyi merkeze almış sorumlu bir kamu yayıncısı anlayışı ile TRT World tweetlerini ürettiği anlaşılmaktadır.

Hesabın Twitter paylaşımlarında en çok kullandığı hashtaglar, potansiyel görüntüleme sıralamasıyla Tablo 2'de sunulmuştur.

Tablo 2 : Kovid-19 Paylaşımlarında Kullanılan Hashtaglar

Top Hashtags

TRT World | Apr 01, 2020 - Apr 30, 2020
Kullandıkları hashtaglerin bașında \#covid, \#breaking, \#coronaviruspandemic ilk sırada yer almaktadır.

\begin{tabular}{lllll} 
Top Hashtags & Tweets & Retweets & All Tweets & Impressions V \\
\hline \#covid19 & 14 & 16 & 30 & 9469044 \\
\hline \#breaking & 3 & 7 & 10 & 3163103 \\
\hline \#coronaviruspandemic & 1 & 3 & 4 & 1261019 \\
\hline \#stayhome & 3 & 1 & 4 & 1258133 \\
\hline \#coronavirus & 2 & 0 & 2 & 628565 \\
\hline \#flattenthecurve & 2 & 0 & 2 & 628382 \\
\hline \#coronajihad & 2 & 0 & 2 & 628356 \\
\hline \#covid & 2 & 0 & 2 & 627500 \\
\hline \#worldbookday & 1 & 0 & 1 & 317157 \\
\hline \#journalismforjuniors & 0 & 1 & 1 & 317156
\end{tabular}


Tablo 2'yi incelediğimizde şu verilere ulaşırız: Paylaşımlarda nisan ayı boyunca üretilen içeriklerde 58 hashtag kullanılmıştir. En yoğun kullanılan hashtag \#covid19 şeklindedir. "\#covid19" hashtagının geçtiği 30 içerik üretilmiş bu içerikler potansiyel olarak 9 milyon 469 bin 44 kez görüntülenmiştir. Kovid 19 paylaşımlarında kullanılan diğer hastaglar \#coronaviruspandemic \#coronavirus \#coronajihad \#covid hastaglarıdır.

Kovid-19 süresince TRT World resmî Twitter hesabından hangi Twitter hesaplarının kaç kez mentionlandığı ve bu tweetlerin potansiyel görüntülenme sayıları Tablo 3'te detaylı olarak yer almaktadır.

Tablo 3: Kovid-19 Paylaşımlarında Mentionlanan Hesaplar

\section{Top Mentions}

TRT World | Apr 01, 2020 - Apr 30, 2020
En çok bahsettikleri hesapların ilk sıralarında TRT World'ün hesapları yer alırken, ABDTürkiye iliş̧kileri Dış Politika Uzmanı, gazeteci @alicinar, Ingiliz gazeteci @martinrjay ve haberci@hyderabbasi listede yer alan isimlerdir.

\begin{tabular}{llccc} 
Most Mentioned Tweeters & Tweets & Retweets & All Tweets & Impressions V \\
\hline @TRTworldnow & 0 & 82 & 82 & 25912809 \\
\hline @presserwatch & 0 & 52 & 52 & 16424384 \\
\hline @the_newsmakers & 0 & 28 & 28 & 8837785 \\
\hline @TRTworld & 18 & 0 & 18 & 5703738 \\
\hline @alicinar & 5 & 0 & 5 & 1577371 \\
\hline @_insideamerica & 0 & 4 & 4 & 1271533 \\
\hline @martinjay & 4 & 0 & 4 & 1267806 \\
\hline @hyderabbasi & 0 & 4 & 4 & 1263312 \\
\hline @jeffflake & 0 & 3 & 3 & 953740 \\
\hline @giorgiocafiero & 3 & 0 & 346245 \\
\hline
\end{tabular}

Bu verilerden hareketle en çok TRT World'ün diğer hesapları mentionlanmıştır. Ayrıca tablo 3'te de görüleceği üzere ABD-Türkiye İlişkileri Dış Politika Uzmanı, gazeteci @alicinar, Ingiliz gazeteci @martinrjay ve haberci @hyderabbasi, bahsedilen diğer Twitter hesapları olmuştur.

Paylaşımlarda en çok kullanılan emojiler ve bu emojilerin bulunduğu tweetlerin retweet sayıları ile potansiyel görüntülenme sayıları ise tablo 4'te sıralanmıştır. 
Tablo 4: Kovid-19 Paylaşımlarında Emoji Kullanımları

Top Emojis

\section{TRT World I Apr 01, 2020 - Apr 30, 2020}
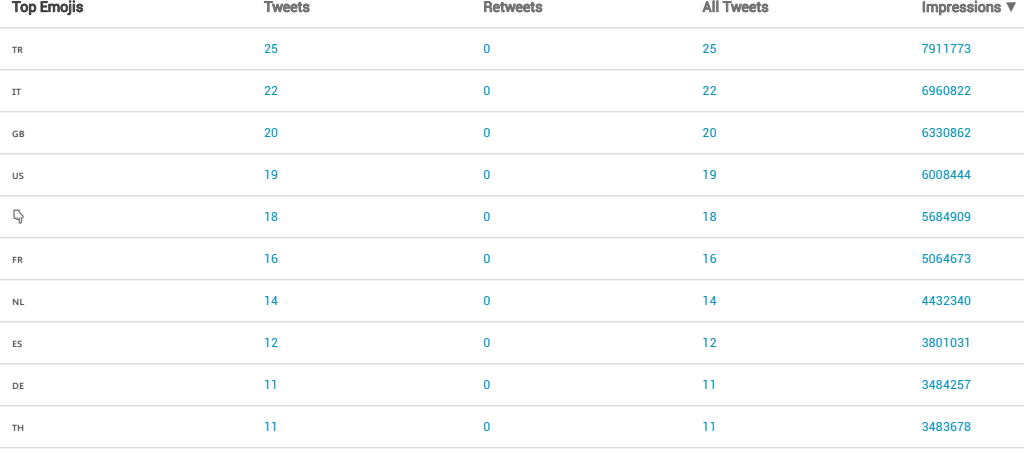

TRT World tarafindan üretilen Kovid-19 paylaşımlarında Türkiye emojisi 25 kez kullanılırken bu paylaşımlar toplamda 7 milyon 911 bin 773 potansiyel görüntüleme almıştı. İtalya emojisi 22, İngiltere 20, Amerika Birleşik Devletleri emojisinin ise 19 kez kullanıldığı tespit edilmiş olup potansiyel görüntülemeleri detaylı bir şekilde tablo 4'te sunulmuştur.

Uygulamanın yapıldığı tarih aralığında üretilen Twitter içerikleri içerisinde; toplam kelime sayısı, en yoğun geçen kelimeler Tablo 5 'te yer alırken ifadenin oranına göre kelimenin fontunun büyümesi şekildeki kurgu ile oluşan kelime bulutu ise resim 4'te ayrıntlı bir şekilde görülmektedir.

Tablo 5 : En Yoğun Geçen Kelimeler

\begin{tabular}{|l|c|c|}
\hline Keyword & Uses & Uses \\
\hline coronavirus & 551 & $1.9 \%$ \\
\hline Kovid-19 & 400 & $1.4 \%$ \\
\hline pandemic & 213 & $0.7 \%$ \\
\hline cases & 210 & $0.7 \%$ \\
\hline people & 166 & $0.6 \%$ \\
\hline death & 150 & $0.5 \%$ \\
\hline toll & 145 & $0.5 \%$ \\
\hline turkey & 140 & $0.5 \%$ \\
\hline lockdown & 127 & $0.4 \%$ \\
\hline
\end{tabular}




\begin{tabular}{|l|c|c|}
\hline death toll & 126 & $0.4 \%$ \\
\hline world & 110 & $0.4 \%$ \\
\hline coronavirus pandemic & 104 & $0.4 \%$ \\
\hline countries & 102 & $0.3 \%$ \\
\hline reports & 100 & $0.3 \%$ \\
\hline \multicolumn{1}{c|}{$\ldots$} & $\ldots$ & $\ldots$ \\
\hline total word count & 29593 & $\% 100$ \\
\hline
\end{tabular}

Kaynak: seoscout.com/tools/keyword-analyzer

Resim 4: TRT World Kovid-19 Paylaşımları Kelime Bulutu

\section{Word Cloud}

\section{TRT World | Apr 01, 2020 - Apr 30, 2020}

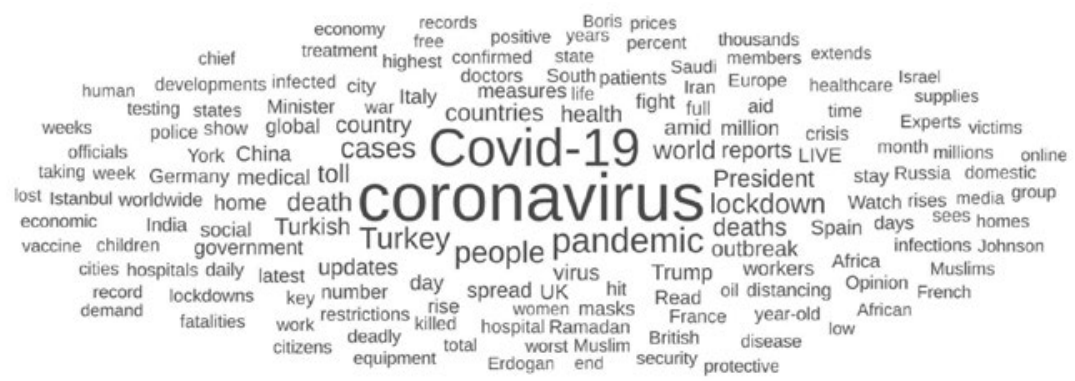

Tablo 5'te görüleceği üzere; Kovid-19 paylaşımlarında toplam 29 bin 593 kelime kullanılmıştrr. Bu kelimeler içerisinde yaklaşık \%2'ye denk gelen 551 kez "coronavirus" kelimesi geçmiştir. 100 ve üzerinde kullanılan kelimeler ile bu kelimelerin oranları Tablo 5 'te tüm detayları ile düzenlenerek sunulmuştur.

Uluslararası bir yayın kuruluşu olarak TRT World'ün kaç farklı lokasyona hitap ettiğini anlamlandırabilmek amacıyla ürettiği Twitter içeriklerinde bahsedilen ülke/ bölge isimleri bin 390 tweetten tespit edilmiştir. Bu doğrultuda Kovid-19 paylaşımlarında geçen yer isimleri, kullanım sıklığı ve geçtikleri tweetin duygu durumları Tablo 6'da yer almaktadır. Paylaşımlarda geçen yerlerin kullanım sıklığına göre hazırlanan kelime bulutları ise Resim 5'te yer almaktadır. 
Tablo 6 : Kovid-19 Paylaşımlarında Geçen Yer İsimleri, Tekrar Sayısı ve Tweet Duygu Durumu

\section{Word Cloud | Location}

TRT World I Apr 01,2020 Apr 30,2020

\begin{tabular}{|c|c|c|c|}
\hline Turkey & Location & Neutral & 223 \\
\hline China & Location & Neutral & 81 \\
\hline Italy & Location & Neutral & 73 \\
\hline Spain & Location & Neutral & 68 \\
\hline Germany & Location & Noutral & 56 \\
\hline New York & Location & Neutral & 47 \\
\hline Africa & Location & Rather negative & 46 \\
\hline India & Location & Neutral & 45 \\
\hline France & Location & Noutral & 40 \\
\hline Russia & Location & Neutral & 40 \\
\hline Europe & Location & Neutral & 36 \\
\hline Iran & Location & Neutral & 36 \\
\hline lstanbul & Location & Neutral & 32 \\
\hline Isracl & Location & Neutral & 22 \\
\hline Mexico & Location & Neutral & 22 \\
\hline South Korea & Location & Neutral & 22 \\
\hline Thailand & Location & Neutral & 22 \\
\hline America & Location & Noutral & 21 \\
\hline
\end{tabular}

Resim 5: Kovid-19 Paylaşımlarında Geçen Yerlerin Kelime Bulutu

\section{Word Cloud I Location}

TRT World | Apr 01, 2020 - Apr 30, 2020

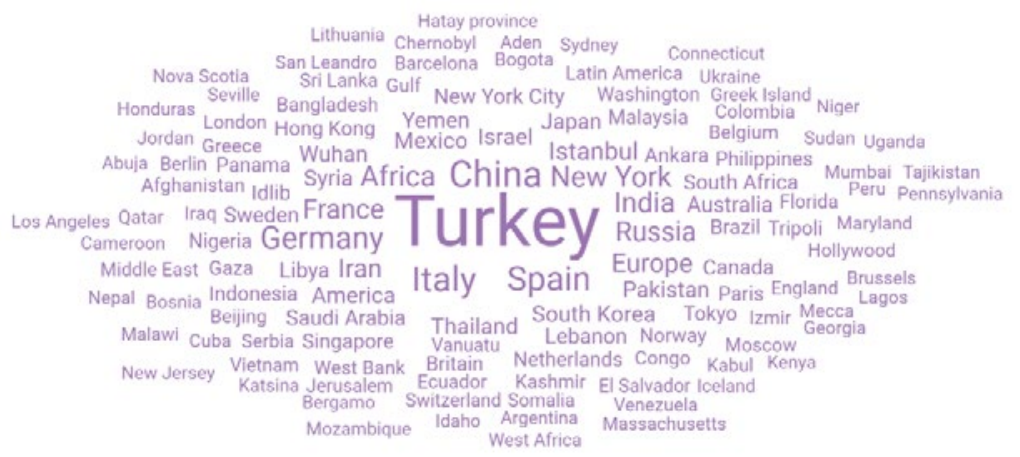

Kovid-19 paylaşımlarının içerik analizi ölçümleri ile üretilen içeriklerin İngilizce okunabilirlik/anlaşılırlık seviyesini ölçen uluslararası ölçüm değerlerini içeren veriler Tablo 7'de detaylı bir şekilde sunulmuştur. 
Tablo 7 : Kovid-19 Paylaşımları İçerik Analizi

\begin{tabular}{|l|c|}
\hline Karakter sayısı (boşluksuz) & $145,772,00$ \\
\hline Kelime sayısı & $29.593,00$ \\
\hline Cümle sayısı & 574.00 \\
\hline Kelime başına ortalama karakter sayısı & 4.93 \\
\hline Kelime başına ortalama hece sayısı & 1.69 \\
\hline Cümle başına ortalama kelime sayısı & 51.56 \\
\hline & \\
\hline Gunning Fog Değeri & 26.28 \\
\hline Coleman Liau Değeri & 12.63 \\
\hline Flesch Kincaid Sınıf seviyesi & 24.48 \\
\hline ARI (Otomatik Okunabilirlik Değeri) & 27.55 \\
\hline SMOG Değeri & 19.47 \\
\hline Flesch Okuma Kolaylığı & 11.40 \\
\hline
\end{tabular}

Kaynak: https://www.online-utility.org/english/readability_test_and_improve.jsp

Tablo 7'de görüleceği üzere üretilen metinlerin okunabilirlik/anlaşılabilirlik değerini farklı formüllerle ortaya koyan; Gunning-Fog değerii", Coleman-Liauiii değeri, Flesch Kincaid ${ }^{i v}$ değeri, ARI ${ }^{v}$ değeri, Smog değerivi ve Flesch Okuma Kolaylığı degerivii tek tek hesaplanarak tablolaştrıımıştr. Gunning-Fog değerinin 26 olması metnin üniversite mezunu seviyesinin de üstünde bir zorluk seviyesinde olduğunu göstermektedir. Flesch-Kincaid readability test sonucu olan 24 üretilen Twitter içeriklerinin okumasının çok zor, en iyi üniversite mezunları tarafindan anlaşılır düzeyde olduğunu bize söylemektedir. The Flesch Reading Ease Readability testinde

\footnotetext{
ii Gunning-Fog Değeri: Gunning'in 1952 yılında kelime uzunluğu ve cümle uzunluğuna göre tanımlamış olduğu bu formül, sadece iki nicelikle metnin hangi yaş grubuna (US grade level) hitap ettiği, buna göre de metnin ne derece kolay veya zor olduğu hakkında bilgi vermektedir (Gunning, 1952).Formülün basit ve kolay hesaplanabilmesinden dolayı birçok ünlü dergi ve gazete bu formülü kendi yayınlarında kullanıp yayınlamışlardır. Detaylı bilgi için https://en.wikipedia.org/wiki/Gunning_fog index

iii Coleman-Liau değeri bir metnin anlaşılabilirliğini ölçmek için basılı metin örneklerinden mekanik olarak kolayca hesaplanacak şekilde tasarlanmıştır. Hece bazlı okunabilirlik indekslerinden farklı olarak kelimelerin karakter içeriklerinin analiz edilmesini gerektirmez, sadece karakter olarak uzunlukları incelenir. Detaylı bilgi için https://tr.qaz.wiki/wiki/Coleman\%E2\%80\%93Liau_index

iv Flesch Kincaid Readability Test : İngilizce metinlerin okuma kolaylığının ölçülmesi için tasarlanmıştır. Ayrıntılı bilgi için https:// en.wikipedia.org/wiki/Flesch\%E2\%80\%93Kincaid_readability_tests

${ }^{v}$ ARI(Automated readability index) değeri: İngilizce bir metnin anlaşılabilirliğinin ölçümü için kullanılmaktadır. Daha detaylı bilgi için: https://en.wikipedia.org/wiki/Automated_readability_index

vi Smog değeri McLaughlin tarafindan 1969 yılında tanımlanan Gobbledygook’un basit ölçüm (SMOG) Değeri, okunabilirlik için basit bir formül olmasına rağmen ABD'de eğitim ve sağlık alanında yazılan metinlerde uzun yıllar boyunca kullanılmamıştır (Hedman, 2008; Ley, 1996).

${ }^{\text {vii }}$ The Flesch Reading Ease Readability Formula: Flesch Okuma Kolaylığı Okunabilirlik Formülü en eski ve en doğru ingilizce okunabilirlik formüllerinden biri olarak kabul edilir. Daha detaylı bilgi için https://readabilityformulas.com/flesch-reading-ease-readability-formula.php
} 
ise 11 sonucuna ulaşılmış, bu sonuç doğrultusunda ise TRT World Ingilizce Twitter metinlerinin çok karışık olduğunu göstermektedir. ARI (Automated Readability Index) değeri 27 çıkmış bu ise ARI viii ölçeklendirilmesi doğrultusunda TRT World metinlerinin okunabilirlik seviyesinin profesör düzeyinde karışık olduğunu göstermektedir.

TRT World'ün Twitter üzerinden yaptı̆̆ Kovid-19 paylaşım metinlerinin karakter sayısı 145 bin 772 olarak belirlenmiştir. 29 bin 593 kelime ve 574 cümleden oluşan bu paylaşımlar da kelime başına ortalama karakter sayısı 4,93, hece sayısı 1,69, cümle başına ortalama kelime sayısı ise 51,56'dır. Tablo 7'de detaylı olarak görüleceği üzere Gunning Fog Değeri: 26.28, Coleman Liau Değeri: 12.63, Flesch Kincaid Sınıf seviyesi:24.48, ARI: 27.55, SMOG Değeri: 19.47 Flesch Okuma Kolaylığı: 11.40 olarak ölçülmüştür (https://app.readable.com/text/?demo\&_ ga=2.210371217.5 02596093.1605349312-350474180.1605 349312). Sonuçta; $\% 85$ metin zenginliği içeren tweetlerini, \%84 oranında nötr duygu durumuna karşılık gelecek şekilde tasarladığı tespit edilmiştir (seoscout.com/tools/keyword-analyzer-app.monkeylearn.com/main/classifiers/cl_pi3C7JiL).

\section{Sonuç}

Çalışmamızda; TRT World Kovid-19 krizi süresince, duygu durumu analizi açısından tarafsız dolayısıyla kriz dönemi sorumlu yayıncılık anlayışında, haber odakIı, cümle başına ortalama kelime sayısı açısından \%85 oranında zengin metin içeriğine sahip, 400'den fazla farklı lokasyondan bahsetmesiyle de uluslararası yayıncılık kriterlerine uygun, potansiyel görüntüleme oranı yüksek olan sosyal medya paylaşımları geliştirdiği sonucuna ulaşılmıştır. Aynı zamanda birden çok okunabilirlik/anlaşılabilirlik ölçümü yapmış olduğumuz bu çalışmamızda TRT World tweet metinlerinin okumasının zor olduğu tespit edilmiştir. Analizler sonucunda ortaya çıkan diğer bir sonuç ise tweetlerde Turkey ifadesi ve Türk bayrağı emojisinin yoğun olarak kullanılmasıdır. Bu sonuçtan anlaşılmaktadır ki Türkiye hakkındaki pandemi haberleri, diğer ülkelerin küresel yayın kuruluşlarının insafina bırakılmamıştır. Bu, çalışmamız açısından oldukça önemli bir analizdir. Çünkü TRT World hem kuruluş amacına uygun bir şekilde uluslararası kamuoyuna Türkiye'deki Kovid-19 gelişmeleri hakkında haberleri yayınlamakta hem de daha önce hiç olmadığı kadar etkili bir şekilde bunu Türkiye'nin kendi perspektifiyle sunmaktadır.

\footnotetext{
viii Arı indeksinde 1 puanın seviye karşılığı olarak "Çocuk Yuvası" seviyesi tanımlanırken bu alınan puana göre: birinci/ikinci sınıf, üçüncü sınıf, dördüncü sınıf, beşinci sınıf, altıncı sınıf, yedinci sınıf, sekizinci sınıf, dokuzuncu sınıf, onuncu sınıf, on birinci sınıf, on ikinci sınıf, üniversite öğrencisi ve profesör olmak üzere 14 seviye bulunmaktadır."
} 
Gerçekleştirilen içerik ve duygu analizleri kapsamında ortaya çıkan sonuçlar doğrultusunda TRT World sosyal medya içerik üreticilerine birtakım öneriler geliştirilmiştir. TRT World Kovid-19 krizi paylaşımlarının Gunning Fog değeri, Coleman Liau değeri, Flesch Kincaid sınıf seviyesi, ARI ve SMOG değerleri doğrultusunda İngilizce metin zenginliğinin oldukça yüksek olduğu tespit edilmiştir. Paylaşımların Flesch-Kincaid readability test sonucu 24 çıkmıştır. Bu sonuca göre üretilen Twitter içeriklerinin anlaşılırlık düzeyinin üniversite mezunu seviyesinde olduğu dolayısıyla okumasının zor olduğu belirlenmiştir. Sosyal medya en temel okuryazardan profesörüne kadar çok fazla çeşitlilikte insanın bulunduğu önemli bir kitle iletişim alanıdır. Böylesi geniş okur yazar yelpazesinin olduğu bir alanda yüksek seviyeli bir dil kullanmak, ulaşacağımız kitleyi daraltabilir. Çalışmamızın bulguları doğrultusunda öncelikle daha basit bir İngilizce ile sosyal medya içeriklerini oluşturması daha fazla insana ulaşması anlamında etkili olacağı düşünülmektedir. Konvansiyonel medyadan farklı olarak sosyal medya iki yönlü ve simetrik bir iletişim doğasına sahiptir. Dolayısıyla kullanıcı odaklı içerikler üretilmesinin, TRT World pandemi paylaşımlarında daha fazla insana ulaşması açısından olumlu bir etki sağlayacağı düşünülmektedir. Bu doğrultuda; takipçilerine Kovid-19'a ilişkin sorular soran, takipçilerinin makul sorularına cevap veren, krizle ilgili anketler oluşturarak takipçilerinin katılmalarını sağlayan, internet sitesine Kovid-19 ile ilgili sık sorulan sorular bölümü oluşturarak bunu Twitter'da kullanıcıları ile paylaşan, Kovid-19'a ilişkin uzman görüşlerinin yer aldığı bilgi yoğun forumlara ve internet sitelerine linkleri Twitter'da paylaşan; kısaca simetrik ve iki yönlü iletişimi merkeze alan Kovid-19 paylaşım stratejisinin, TRT World'ün Twitter'daki etkileşimine katkı sağlayacağı düşünülmektedir.

TRT World Kovid-19 krizi süresince insanları bilgilendirmeye yönelik ürettiği haberleri düzenli bir biçimde sosyal medyadan yayınlamış, uluslararası bir kamu yayıncısı olarak kriz haberciliğini sosyal medya üzerinden başarılı bir şekilde uygulamıştır.

\section{Kaynakça}

AKGÜNER, Tayfun. (1996), "Kamu Hizmeti Yayıncılığı ve TRT" Yeni Türkiye Dergisi, Kasım-Aralık, Yıl 2, Sayı 12.

BAL, E. (2018). “Kamuoyu Oluşumunda Güçlü Bir Unsur Olarak Dış Yayınclık ve Dış Yayıncılıkta İçeriğin Önemi". Humanities Sciences , 13 (3) , 74-83.

ÇAPLI Bülent, Oğuzhan Taş; Kriz haberciliği, Televizyon haberciliğinde etik, https://www.academia. edu/3823922/Kriz_Haberciliği?source=swp_share

DEVRAN, Yusuf. (2015). Yeni Türkiye'nin Küresel Sesi TRT World: Fırsatlar ve Güçlükler. E-journal of Intermedia. 2. 281-294.

GiDDENS, Anthony(2000) "Siyaset, Sosyoloji ve Toplumsal Teori" Metis Yayınları 6. Baskı. HOLTZ S (1999) Public Relations on the NET, American Management Association, USA. 
KARLI, İhsan; Dondurucu Zeynep Benan (2020). "Eleştirel Söylem Çözümlemesi Bağlamında Fox News ve CNN'in COVID-19 Salgınında Twitter Kullanımı". İnsan\&insan, Yıl:7, Sayı:26, Güz 2020, 163-186

KOÇAK, A. ve Arun, Ö. (2006). İçerik analizi çalışmalarında örneklem sorunu. Selçuk iletişim, 4(3). Kul:(2020). Dijital okuryazarlık ve diğer değişkenlerle internet bağımlıı̆ı ilişkisinin incelenmesi. Uluslararası Yönetim Bilişim Sistemleri ve Bilgisayar Bilimleri Dergisi, 4(1), 28-41.

MEYERS, Christopher (1993). "Justifying Journalistic Harms: Right to Know vs. Interest in Knowing." Journal of Mass Media Ethics 8(3): 133-146.

ONAN, A . (2017). Twitter Mesajları Üzerinde Makine Öğrenmesi Yöntemlerine Dayalı Duygu Analizi . Yönetim Bilişim Sistemleri Dergisi, 3 (2), 1-14.

RiTZER, G. (2011). Küresel dünya (M. Pekdemir, Çev.): Ayrınt Yayınları.

SAFALI Y, Avaroğlu E., Ergen B.(2018). "Twitter Verilerinden Kullanıcıların Siyasi Eğilimlerinin Veri Madenciliği Teknikleri ile Kestirimi," 2018 International Conference on Artificial Intelligence and Data Processing (IDAP), Malatya, Turkey, 2018, pp. 1-5, doi: 10.1109/IDAP.2018.8620747.

SCHMIDT, Eric, Jared Cohen(2015). "Yeni Dijital Çağ: İnsanların, Ulusların ve İş Dünyasının Geleceğini Yeni Baştan Şekillendirmek", Çeviren: Ümit Şensoy, Optimist Yayınları

TÜYSÜZ, Suat, Başıbüyük, Adem Binali(2018). "Küreselleşme Nereye?" TÜCAUM 30. Yıl Uluslararası Coğrafya Sempozyumu sonuç bildirgesi sf: 1220-1224 3-6 Ekim 2018 Ankara

YANARDAĞ, U . (2020). Sosyal Çalışmacıların Yazılı Basında Temsili Üzerine Bir Nitel Araştırma . Türkiye Sosyal Hizmet Araştırmaları Dergisi , 4 (2) , 1-8.

\section{Internet Siteleri}

-https://www.nielsen.com/us/en/insights/article/2020/COVID-19 -key-questions-all-marketers-should-be-asking/ 2020 Nielsen Medya Tüketim Raporu,

-https://reutersinstitute.politics.ox.ac.uk/trust-uk-government-and-news-media-COVID-19 -information-down-concerns-over-misinformation - 2020 Reuters İngiltere Koronavirüs Medya ve Enformasyon Raporu

-https://socialblade.com/Twitter/user/trtworld

-https://www.online-utility.org/text/analyzer.jsp

-https://voyant-tools.org/?corpus=470ce122eeded1419cb05f8241880ce5

-https://dash.tweetbinder.com/report/c85750c0

-https://www.twitonomy.com/search.php?q=\%40trtworld

-twitonomy.com/profile.php?sn=trtworld

-brandwatch.com

-adbaanalytics.com

-seoscout.com

-keyhole.co 